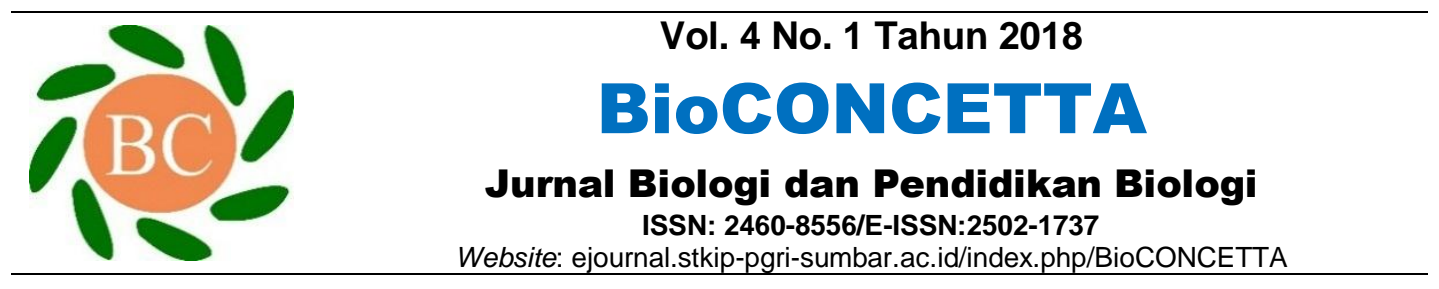

\title{
Pengembangan LKS Materi Sistem Regulasi Manusia Dilengkapi Teka-Teki Silang untuk SMA
}

\section{Sri Nengsi}

Program Studi Pendidikan Biologi STKIP Abdi Pendidikan Payakumbuh,

Alamat: Jl. Prof. M Yamin Payakumbuh, Sumatera Barat (26212) Indonesia

Email: Srinengsi1982@gmail.com

\section{Info Artikel}

Sejarah Artikel

Diterima:

4 Juli 2018

Disetujui:

30 Agustus 2018

Dipublikasikan:

31 Agustus 2018

Kata Kunci:

LKS, sistem regulasi, teka-teki silang

Keywords: LKS, system of regulation, crossword

\begin{abstract}
Abstrak
LKS yang digunakan oleh guru dalam proses pembelajaran masih ditemukan gambar belum berwarna, soal-soal latihan berupa objektif, desain LKS belum menarik dan bervariasi. Ini menyebabkan kurangnya minat siswa untuk belajar. Tujuan penelitian adalah untuk mempermudah siswa memahami materi sistem regulasi manusia dan meningkatkan minat siswa dalam belajar. Penelitian ini merupakan penelitian pengembangan dengan menggunakan tiga tahap dari model 4-D, yaitu pendefinisian (define), perancangan (design), dan pengembangan (develop). Hasil pengolahan data dari angket validasi, menghasilkan rata-rata sebesar $77 \%$ yang tergolong dalam kategori valid. Hasil pengujian angket praktikalitas respon guru memperoleh rata-rata sebesar $85,50 \%$ dengan kategori sangat praktis dan rata-rata praktikalitas respon siswa sebesar $87,62 \%$ dengan kategori sangat praktis. Dengan demikian dapat disimpulkan, LKS yang dikembangkan, sudah valid dan praktis digunakan oleh guru dan siswa, sehingga layak untuk dijadikan LKS pembelajaran biologi.
\end{abstract}

\footnotetext{
Abstract

LKS used by teachers in the learning process still found the picture is not colored, the exercise problems are objective, the design of the LKS has not been interesting and varied. This causes a lack of student interest to learn. The purpose of the research is to make it easier for students to understand the material of the human regulation system and to increase the students' interest in learning. This research is a development research by using three stages of 4-D model, namely define, design, and development. The results of data processing from validation questionnaire, resulting in an average of $77 \%$ belonging to the category valid. The result of questionnaire test of teacher's responsiveness is $85,50 \%$ with very practical category and the average of students practice response is $87,62 \%$ with very practical category. Thus it can be concluded, LKS developed, has been valid and practical use by teachers and students, so feasible to be made LKS biology learning.
} 


\section{PENDAHULUAN}

IPA merupakan konsep pembelajaran mengenal alam dan mempunyai hubungan yang sangat luas terkait dengan kehidupan manusia. Pembelajaran IPA sangat berperan dalam proses pendidikan dan juga perkembangan teknologi, karena IPA memiliki upaya untuk membangkitkan minat manusia serta kemampuan dalam mengembangkan ilmu pengetahuan dan teknologi serta pemahaman tentang alam semesta yang mempunyai banyak fakta yang belum terungkap dan masih bersifat rahasia sehingga hasil penemuannya dapat dikembangkan menjadi ilmu pengetahuan alam yang baru dan dapat diterapkan dalam kehidupan seharihari.

Salah satu cabang dari IPA adalah Biologi. Biologi memiliki karakteristik tersendiri dibandingkan dengan ilmu-ilmu alam lainnya. Belajar Biologi berarti berupaya mengenal makhluk hidup dan proses kehidupannya dilingkungan. Pembelajaran Biologi sebaiknya dilaksanakan dengan pendekatan yang berpusat pada siswa (student centered) dan berorientasi pada proses, tidak hanya pada hasil. Di samping itu, pembelajaran Biologi juga harus menyenangkan, agar siswa tertarik dan meningkatkan motivasi belajar mereka (Resfianti, 2015:2).

Pembelajaran Biologi yang efektif juga harus ditunjang oleh berbagai sumber belajar yang mendukung dan relevan. Sumber belajar utama yang dapat digunakan dalam pembelajaran Biologi dapat berbentuk teks tertulis seperti buku, majalah, brosur, surat kabar, poster dan informasi lepas, atau berupa lingkungan sekitar, seperti lingkungan alam dan lingkungan sosial sehari-hari (Trianto, 2010:121).

Salah satu sumber belajar yang penting dalam proses pembelajaran Biologi adalah bahan ajar. Bahan ajar merupakan suatu unsur yang perlu mendapat perhatian oleh guru. Karena dengan bahan ajar, para siswa dapat mempelajari hal-hal yang diperlukan dalam upaya mencapai tujuan belajar (Hamalik, 2011:51). Oleh karena itu, guru harus mampu dalam mengembangkan bahan ajar ke dalam bentuk buku yang mudah diperbanyak, yaitu dalam bentuk cetak, dapat berupa handout, LKS, modul, maupun diktat. Bahan ajar yang dikembangkan 
disusun secara sistematis yang memungkinkan siswa dapat belajar secara mandiri dan dirancang sesuai kurikulum yang berlaku.

Proses pembelajaran belum sepenuhnya berlangsung secara optimal. Berdasarkan hasil wawancara yang penulis lakukan dengan guru Biologi SMA N 1 Kecamatan Lareh Sago Halaban diperoleh informasi bahwa dalam proses pembelajaran, guru menggunakan LKS sebagai sumber utama bahan belajar. LKS yang digunakan dibeli dari pasaran sesuai dengan kurikulum KTSP. Dalam proses pembelajaran, guru menggunakan LKS sebagai sumber utama bahan belajar. LKS yang digunakan dibeli dari pasaran sesuai dengan kurikulum KTSP. Materi yang terdapat dalam LKS tersebut belum dilengkapi dengan gambar yang berwarna. Selain itu, soal-soal latihannya hanya berupa pertanyaanpertanyaan berbentuk objektif, isian dan essay saja, tanpa adanya variasi lain untuk menarik minat siswa dalam mengerjakan latihan. Selain itu, desain LKS belum menarik dan bervariasi.

LKS adalah lembaran-lembaran berisi tugas yang harus dikerjakan oleh siswa (Depdiknas, 2008:25). LKS merupakan salah satu sumber belajar yang dapat dikembangkan oleh guru sebagai fasilitator dalam kegiatan pembelajaran. LKS yang disusun dapat dirancang dan dikembangkan sesuai dengan kondisi dan situasi kegiatan pembelajaran yang akan dihadapi. LKS yang akan penulis kembangkan yaitu LKS yang menarik dan dilengkapi gambar yang berwarna. Materi yang akan disajikan jelas, sesuai dengan kurikulum dan mudah dipahami oleh siswa. Soal-soal latihan juga bervariasi yaitu berupa teka-teki silang sebagai tugas mandiri dan soal menjodohkan sebagai uji kemampuan.

Teka-teki silang merupakan sebuah permainan yang cara permainannya yaitu mengisi ruangruang kosong yang berbentuk kotak dengan huruf-huruf sehingga membentuk sebuah kata yang sesuai dengan petujuk. Mengisi teka-teki silang sangat mengasyikkan dan dapat membangkitkan semangat belajar siswa, karena teka-teki silang dapat membangkitkan rasa ingin tahu dan membuat siswa merasa tertantang untuk menyelesaikan seluruh pertanyaan yang diajukan di dalam teka-teki silang. Hal ini dapat menarik minat siswa dalam menulis dan 
membaca. Siswa akan berusaha menyelesaikan seluruh pertanyaan dengan benar. Selain itu, dengan tekateki silang, juga dapat meningkatkan kemampuan siswa untuk fokus dan konsentrasi dalam belajar. Sehingga siswa akan lebih mudah menyerap pelajaran (Niahidayat dalam Khalilullah, 2012:23).

Menurut Widjajanti (2008:2) LKS mempunyai beberapa fungsi yaitu; (1) merupakan alternatif bagi guru untuk mengarahkan pengajaran atau memperkenalkan suatu kegiatan tertentu sebagai kegiatan belajar mengajar, (2) dapat digunakan untuk mempercepat proses pengajaran dan menghemat waktu penyajian suatu topik, (3) dapat untuk mengetahui seberapa jauh materi yang telah dikuasai siswa, (4) dapat mengoptimalkan alat bantu pengajaran yang terbatas, (5) membantu siswa dapat lebih aktif dalam proses belajar mengajar, (6) dapat membangkitkan minat siswa jika LKS disusun secara rapi, sistematis mudah dipahami oleh siswa sehingga mudah menarik perhatian siswa, (7) dapat menumbuhkan kepercayaan pada diri siswa dan meningkatkan motivasi belajar dan rasa ingin tahu, (8) dapat mempermudah penyelesaian tugas perorangan, kelompok atau klasikal karena siswa dapat menyelesaikan tugas sesuai dengan kecepatan belajarnya, (9) dapat digunakan untuk melatih siswa menggunakan waktu seefektif mungkin, dan (10) dapat meningkatkan kemampuan siswa dalam memecahkan masalah.

Dalam pembuatan LKS harus ada struktur-struktur yang mencakup isi keseluruhan LKS. Menurut Depdiknas (2008:26) struktur LKS secara umum adalah sebagai berikut; (1) judul, (2) petunjuk belajar (petunjuk siswa), (3) Kompetensi yang akan dicapai, (4) informasi pendukung, (5) tugas-tugas dan langkah kerja, dan (6) penilaian.

LKS mempunyai kelebihan dan kekurangan. Menurut Belawati (2006:1-14) menyimpulkan kelebihan dan kekurangan LKS. Kelebihan LKS adalah; (a) mudah diperoleh dan harga lebih terjangkau, (b) bisa dipelajari dimana saja, (c) tidak membutuhkan alat khusus dan mahal untuk memanfaatkannya, (d) Informasi didalamnya mudah diakses, dan (e) dalam kualitas penyampaian LKS memaparkan kata-kata, gambar, dan lembar latihan (tugas). Sedangkan 
kekurangan LKS adalah (a) tidak bisa menampilkan gerakan, dan membutuhkan biaya yang cukup tinggi untuk memproduksi LKS.

Menurut Uinsby (2011:27) kelebihan dan kelemahan teka-teki silang. Kelebihan teka-teki silang adalah; (a) permainan dapat dipakai untuk membangkitkan kembali kegairahan belajar siswa yang mulai bosan, (b) materi yang dikomunikasikan lewat permaianan biasanya mengesan, sehingga sukar dilupakan, (c) teka-teki silang relatif murah dan mudah didapatkan atau disiapkan, dan (d) cara bermainnya termasuk mudah yaitu dengan mengisi jawaban dari pertanyaan yang tersedia baik vertikal maupun horizontal. Kelemahan teka-teki silang adalah; (a) kata-kata yang dibentuk cenderung pendek, dan (b) untuk membentuk isi jawaban dari teka-teki silang yang saling berhubungan memerlukan pengetahuan perbendaharaan kata yang banyak.

Tujuan dari penelitian ini adalah untuk menghasilkan LKS yang dilengkapi teka-teki silang pada materi Sistem Regulasi Manusia yang valid dan untuk menghasilkan LKS yang dilengkapi teka-teki silang pada materi
Sistem Regulasi Manusia yang praktis digunakan.

\section{BAHAN DAN METODE}

Penelitian ini merupakan penelitian pengembangan dengan menggunakan model pengembangan 4-D (four D), yang terdiri dari 4 tahap. Tahap-tahap itu adalah pendefinisian (define), perancangan (design), pengembangan (develop), dan penyebaran (disseminate). Mengingat adanya keterbatasan dalam penelitian maka pengembangan ini hanya berlangsung sampai tahap develop (pengembangan) saja. Model pengembangan pembelajaran 4-D untuk LKS pada penelitian ini bisa dilihat pada Gambar 1.

Pada tahap pendefinisian (define) yaitu melakukan analisis kurikulum untuk memunculkan masalah dasar yang dibutuhkan dalam pengembangam LKS. Menganalisis SK dan KD yang terdapat dalam KTSP SMA kelas XI semester II, yaitu pada materi sistem regulasi manusia. Dilanjutkan dengan menganalisis siswa yang meliputi usia, tipe belajar siswa, kemampuan akademik dan motivasi terhadap mata pelajaran. Kemudian analisis konsep dilakukan 
dengan mengidentifikasi konsep- diajarkan pada materi sistem regulasi konsep atau materi utama yang perlu manusia untuk SMA kelas XI.

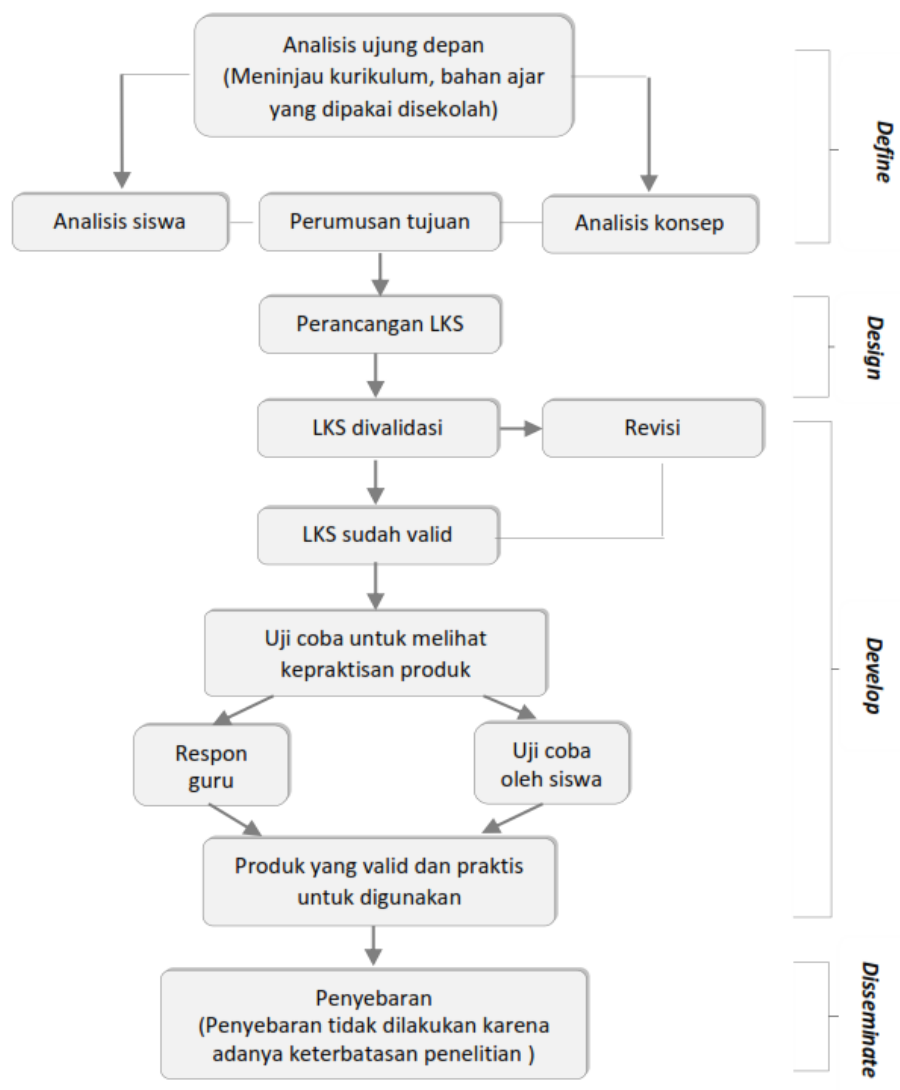

Gambar 1. Model pengembangan pembelajaran 4-D untuk LKS

Pada tahap perancangan (design) validasi dan tahap praktikalisasi yaitu melakukan beberapa proses terhadap LKS yang dilengkapi tekadesign, diantaranya adalah; (a) teki silang. Validasi dilakukan oleh mendesain LKS yang dilengkapi teka- guru yang mengajar di SMA, dan teki silang pada materi sistem regulasi dosen sedangkan praktikalitas manusia pada pembelajaran biologi dilakukan oleh guru dan siswa. Data kelas XI, (b) mendesain instrumen yang dianalisis adalah data hasil penelitian, yaitu: (1) lembar validasi validasi LKS yang dilengkapi teka-teki LKS yang dilengkapi teka-teki silang, silang yang telah dirancang dengan dan (2) lembar praktikalitas LKS. Pada sedemikian rupa. LKS ini dapat dilihat tahap pengembangan dilakukan tahap 
kelayakannya melalui penilaian dari pakar (dosen dan guru).

Menurut Afrianto, Gusmaweti dan Hendri (2015:5) data dianalisis dengan mencari persentase $(\%)$ dengan rumus persentase.

$\mathrm{V}=\frac{\text { jumlah skor yang diperoleh }}{\text { jumlah skor tertinggi }} \mathrm{X} 100 \%$

Berdasarkan hasil yang diperoleh, ditentukan kevalidan LKS yang dilengkapi teka-teki silang yang telah dikembangkan dengan menggunakan kriteria; sangat valid (81-100\%), valid (61-80\%), cukup valid (41-60\%), kurang valid (21-40\%) dan tidak valid (0-20\%) (Modifikasi Wasgito dan Setiadarma, 2014:42).

Analisis data praktikalitas LKS Biologi menggunakan angket respon guru dan siswa. LKS ini bisa dilihat kepraktisannya melalui penilaian dari guru dan siswa yang menggunakan LKS Biologi yang dikembangkan. Menurut Sudijono (2012:43) data dianalisis dengan mencari persentase (\%) dengan rumus sebagai berikut.

$P=(f / N) \times 100 \%$.

(P; nilai persentase yang akan dicari, f; frekuensi yang sedang dicari persentasenya, dan $\mathrm{N}$; jumlah frekuensi)

Data yang terkumpul diolah dengan teknik persentase. Setelah data persentase diperoleh lalu dilakukan pengelompokkan sesuai kriteria, yaitu; sangat praktis (81-100\%), praktis (61$80 \%)$, cukup praktis (41-60\%), kurang praktis (21-40\%), dan tidak praktis (020\%) (Modifikasi Wasgito dan Setiadarma, 2014:42).

Penelitian ini dilakukan pada bulan April sampai dengan bulan Mei.Adapun subjek uji coba dalam penelitian ini adalah siswa kelas XI IPA 2. Penelitian ini dilakukan di SMA N 1 Kecamatan Lareh Sago Halaban yang berjumlah 29 orang.

\section{HASIL DAN PEMBAHASAN}

Berdasarkan hasil analisis pada tahap define, LKS yang dilengkapi teka-teki silang yang telah dikembangkan untuk SMA kelas XI, terdiri dari SK, KD dan Indikator berdasarkan kurikulum KTSP. Subjek dalam penelitian ini adalah siswa kelas XI IPA 2 SMA N 1 Kecamatan Lareh Sago Halaban yang berusia antara 1618 tahun. Siswa di kelas ini memiliki karakteristik yaitu siswa belajar tidak hanya bergantung pada guru saja, tetapi sudah mulai mampu berpikir kritis dan belajar secara mandiri.

Pada penelitian ini konsepkonsep yang terdapat dalam LKS yang dilengkapi teka-teki silang yaitu; (a) 
sistem saraf, terdiri dari sistem saraf pusat dan sistem saraf tepi, (b) sistem indra, terdiri dari indra penglihat, indra pendengar, indra peraba, indra pembau, indra pengecap, dan (c) sistem hormon, dihasilkan oleh kelenjar endokrin. Setelah tahap define selesai maka tahap selanjutnya yang dilakukan adalah tahap design. LKS yang telah selesai dikembangkan terdiri dari: cover, kata pengantar, daftar isi, pendahuluan, petunjuk penggunaan, standar kompetensi, kompetensi dasar, indikator, tujuan pembelajaran, peta konsep, uraian materi, kegiatan siswa, tugas mandiri, rangkuman, kata kunci, refleksi, evaluasi, daftar pustaka dan sampul.

Setelah proses perancangan LKS selesai, kemudian dilanjutkan ke tahap pengembangan yaitu dilakukan validasi dan praktikalisasi. Validasi LKS yang dilengkapi teka-teki silang dilakukan oleh 3 orang validator dengan menggunakan lembaran validasi. Hasil validasi LKS yang dilengkapi teka-teki silang dari validator dapat dilihat pada Tabel 1.

Tabel 1. Hasil Validasi LKS yang Dilengkapi Teka-Teki Silang

\begin{tabular}{clcc}
\hline No & \multicolumn{1}{c}{ Aspek yang Divalidasi } & Hasil & Kategori \\
\hline 1. & Syarat didaktik & $80 \%$ & Valid \\
2. & Syarat konstruksi & $80 \%$ & Valid \\
3. & Syarat teknis & $78,88 \%$ & Valid \\
4. & Karakteristik teka-teki silang & $72,22 \%$ & Valid \\
& & $77 \%$ & Julid \\
\hline
\end{tabular}

Nilai validasi tertinggi dari hasil penilaian terdapat pada syarat didaktik dan kontruksi. Hal ini menunjukkan bahwa syarat didaktik pada materi sistem regulasi manusia pada LKS yang dikembangkan telah mengacu pada kurikulum yang berlaku yaitu KTSP. Hal ini sesuai dengan pendapat yang dikemukakan oleh Belawati (2006:25) yang mengatakan bahwa acuan utama dalam penentuan kedalaman dan keluasan isi bahan ajar adalah kurikulum.

Berdasarkan nilai hasil validasi yang diperoleh untuk syarat konstruksi, LKS dinyatakan memenuhi syarat konstruksi karena uraian materi dalam LKS disajikan dengan jelas dengan kalimat yang mudah dipahami. Kalimat yang digunakan tidak menimbulkan penafsiran yang salah dalam menjelaskan konsep sehingga 
memudahkan siswa untuk memahami materi dalam LKS. Selain itu, LKS juga memiliki identitas yang jelas. Hal ini sesuai dengan pendapat yang dikemukakan oleh Darmojo dan Kaligis dalam Widjajanti (2008:3) yang mengatakan bahwa syarat konstruksi penyusunan LKS yaitu penggunaan bahasa, susunan kalimat, kosakata, tingkat kesukaran dan kejelasan, pada hakikatnya haruslah tepat guna dalam arti dapat dimengerti oleh siswa.

Selanjutnya nilai hasil validasi yang diperoleh untuk syarat teknis menunjukkan bahwa produk yang dikembangkan memiliki tulisan dengan menggunakan huruf yang jelas dan materi dilengkapi dengan gambar yang jelas dan sesuai dengan materi sistem regulasi manusia. Selain itu, LKS memiliki bentuk penampilan yang menarik. Hal ini sejalan dengan pendapat yang dikemukakan oleh Darmojo dan Kaligis dalam Widjajanti (2008:4) yang mengatakan bahwa syarat teknis penyusunan LKS yang baik yaitu LKS harus memperhatikan tulisan, gambar dan penampilan.
Kemudian nilai hasil validasi yang diperoleh untuk karakteristik teka-teki silang menunjukkan bahwa LKS yang dilengkapi teka-teki silang memiliki soal yang jelas dan mudah dipahami, dapat membangkitkan rasa ingin tahu dan membangkitkan kembali semangat dalam belajar. Berdasarkan syarat penilaian validasi LKS yang dilengkapi teka-teki silang pada materi sistem regulasi manusia yang telah dilakukan oleh 3 orang validator dapat disimpulkan bahwa LKS yang dilengkapi teka-teki silang pada materi sistem regulasi manusia yang dikembangkan telah sesuai dengan kebutuhan di SMA kelas XI sehingga layak untuk diujicobakan kepada siswa.

Selanjutnya, uji coba produk untuk mengetahui praktikalitas LKS dilakukan secara terbatas di kelas XI IPA $_{2}$ SMA N 1 Kecamatan Lareh Sago Halaban dengan jumlah siswa sebanyak 29 orang dan 2 orang guru Biologi. Penyajian data hasil praktikalitas oleh guru dapat dilihat pada Tabel 2. 
Tabel 2. Hasil Analisis Angket Respon Guru Terhadap LKS yang Dilengkapi Teka-Teki Silang

\begin{tabular}{|c|c|c|c|}
\hline No & Aspek yang praktikalisasi & $\begin{array}{c}\text { Nilai } \\
\text { Praktikalitas }\end{array}$ & kategori \\
\hline 1 & Bentuk LKS & $90 \%$ & Sangat praktis \\
\hline 2 & Isi LKS & $82,85 \%$ & Sangat praktis \\
\hline \multirow[t]{2}{*}{3} & Kepraktisan LKS & $85,55 \%$ & Sangat praktis \\
\hline & Jumlal & $85,50 \%$ & Sangat praktis \\
\hline
\end{tabular}

Hasil uji praktikalitas tertinggi terdapat pada aspek bentuk LKS. Hal ini menunjukkan penampilan LKS yang dilengkapi teka-teki silang menarik, huruf dan tulisan jelas serta petunjuk penggunaan LKS jelas dan mudah dipahami. Hal ini sesuai dengan pendapat Smaldino, Lowther dan Russell dalam Cahyani, Ardi dan Amri (2014:4) menyatakan bahwa gaya dari teks seharusnya konsisten dan selaras dengan unsur-unsur visual lainnya, ukuran dan spasi disesuaikan sehingga mudah dibaca begitu juga dengan warna teks yang dibuat harus kontras dengan warna latar belakang.

$$
\text { Selanjutnya nilai hasil }
$$
praktikalitas yang diperoleh untuk aspek kepraktisan menunjukkan bahwa LKS yang dilengkapi teka-teki silang dapat membantu memudahkan guru dalam menyampaikan materi pelajaran kepada siswa sehingga dapat mencapai tujuan pembelajaran. Karena setiap siswa telah memiliki LKS yang dilengkapi teka-teki silang dan dapat mempelajarinya masing-masing, jadi guru tidak perlu terlalu banyak lagi menjelaskan materi, sehingga dapat mengefisienkan waktu. Hal ini sesuai dengan pendapat Prastowo dalam Cahyani, Ardi dan Amri (2014:5) yang menyatakan bahwa bahan ajar dapat menghemat waktu pendidik dalam mengajar.

Sedangkan nilai hasil praktikalitas yang diperoleh untuk aspek isi LKS menunjukkan LKS telah sesuai dengan kurikulum KTSP maupun dengan SK dan KD, selain itu gambar dalam LKS sudah sesuai dengan konsep materi Sistem Regulasi Manusia serta dilengkapi keterangan gambar. Hal ini diperkuat oleh pendapat Belawati (2006:23) bahwa bahan ajar tidak dikembangkan secara asal-asalan, tetapi berdasarkan konsep dan teori yang berlaku, sehingga isi dapat dipertanggungjawabkan secara ilmiah dan benar dari segi keilmuan.

Berdasarkan nilai hasil praktikalitas yang diperoleh dari ketiga 
aspek kepraktisan oleh guru dapat disimpulkan bahwa LKS yang dilengkapi teka-teki silang dapat membantu dan memudahkan guru dalam menyampaikan materi pembelajaran Biologi khususnya pada materi sistem regulasi manusia kepada siswa.

Praktikalitas LKS selanjutnya dinilai oleh siswa. Penyajian data hasil uji praktikalitas oleh siswa dapat dilihat pada Tabel 3.

Tabel 3. Hasil Analisis Angket Respon Siswa Terhadap LKS yang Dilengkapi Teka-teki Silang

\begin{tabular}{|c|c|c|c|}
\hline No & Aspek Penilaian & $\begin{array}{c}\text { Nilai } \\
\text { Praktikalitas }\end{array}$ & Kriteria \\
\hline 1. & Bentuk LKS & $91,20 \%$ & Sangat praktis \\
\hline 2. & Isi LKS & $87,41 \%$ & Sangat praktis \\
\hline \multirow[t]{2}{*}{3.} & Kepraktisan LKS & $86,46 \%$ & Sangat praktis \\
\hline & Jumlah & $87,62 \%$ & Sangat praktis \\
\hline
\end{tabular}

Hasil uji praktikalitas tertinggi terdapat pada aspek bentuk LKS. Hal ini menunjukkan bahwa penampilan LKS menarik, huruf dan tulisan LKS jelas serta menarik dan petunjuk penggunaan LKS jelas. Hal tersebut terbukti ketika proses pembelajaran, siswa asyik menggunakan LKS dan mengisi teka-teki silang yang terdapat dalam LKS.

Selanjutnya nilai hasil praktikalitas untuk aspek isi LKS yang yang diperoleh menunjukkan LKS yang dilengkapi teka-teki silang sesuai dengan konsep materi dan sesuai dengan $\mathrm{SK}, \mathrm{KD}$, indikator sehingga membantu siswa menguasai tujuan pembelajaran. Selain itu gambar didalam LKS yang dilengkapi teka- teki silang sesuai dengan materi, jelas dan berwarna serta ada keterangan gambar yang jelas. Sehingga memudahkan siswa memahami materi sistem regulasi manusia. Hal ini sejalan dengan pendapat Brown dalam Afriani, Ananda dan Sumarmin (2013:3) menyatakan bahwa gambargambar yang ditampilkan secara tepat akan membantu siswa memahami dan mengingat materi yang menyertainya.

Kemudian untuk penilaian kepraktisan LKS yang diperoleh menunjukkan bahwa LKS yang dilengkapi teka-teki silangdapat membantu siswa lebih aktif dalam kegiatan pembelajaran dan LKS mudah dipahami, serta dapat dipelajari secara mandiri. Sehingga 
memudahkan siswa dalam belajar. Hal ini sesuai pendapat Belawati (2006:26) mengatakan bahwa bahan ajar perlu memiliki alat bantu yang dapat mempermudah siswa dalam mempelajari bahan ajar tersebut, yang dikenal dengan nama Mnemonic Devices (alat bantu mengingat atau belajar). Selain itu, TTS dalam LKS dapat menghilangkan kejenuhan dan dapat meningkatkan motivasi dalam belajar.

Berdasarkan nilai hasil uji praktikalitas LKS yang dilengkapi teka-teki silang yang diisi oleh siswa menunjukkan bahwa LKS yang telah dikembangkan pada materi sistem regulasi manusia mampu menarik minat siswa untuk mempelajarinya sehingga mampu membantu siswa dalam memahami materi.

Berdasarkan hasil angket uji praktikalitas oleh guru dan siswa dapat disimpulkan bahwa LKS yang dilengkapi teka-teki silang yang telah dirancang dapat memudahkan guru dan siswa dalam kegiatan proses pembelajaran. Hal ini berarti LKS yang dilengkapi teka-teki silang pada materi sistem regulasi manusia yang telah dirancang dapat digunakan dalam proses pembelajaran. Penyataan ini sesuai dengan pendapat Richey dan Nelson dalam Maret (2009:100) yang mengatakan bahwa suatu produk dikatakan pratikal apabila produk tersebut menganggap bahwa ia dapat digunakan (usable) dan kepraktisan suatu produk ditinjau dari hasil penilaian pengamat berdasarkan pengamatannya menyatakan bahwa tingkat pengelolaan pembelajaran di kelas termasuk pada kategori yang baik.

\section{SIMPULAN}

Berdasarkan hasil penelitian dan pembahasan maka dapat disimpulkan bahwa LKS yang dilengkapi teka-teki silang yang dikembangkan pada materi sistem regulasi manusia untuk siswa kelas XI SMA berhasil dilakukan dengan valid dan praktis sehingga dapat digunakan dalam pembelajaran.

\section{DAFTAR PUSTAKA}

Afriani, Ananda, dan Sumarmin. 2013. Pengembangan Modul Bergambar Dilengkapi LKS Dengan Pendekatan Jas pada Pembelajaran Materi Sistem Organ untuk Siswa SMA Kelas XI Semester Genap. (http://ejournal. unp.ac.id. Diakses 7 Juni 2016.

Afrianto, Gusmaweti dan Hendri. 2015. Pengembangan Handout Dilengkapi dengan Teka-teki Silang pada Pembelajaran 
Biologi Materi Sistem Ekskresi di MAN 1 Muara Bungo. (http://ejurnal.bunghatta.ac.id. Diakses 16 Februari 2016.

Belawati, T. 2006. Pengembangan Bahan Ajar. Jakarta: Universitas Terbuka.

Cahyani, Ardi, dan Amri. 2014. Pengembangan Handout Bernuansa Kontekstual pada Materi Sistem Regulasi Manusia untuk SMA. (http://ejournal-s1pgri-sumbar. ac.id. Diakses 7 Juli 2016.

Depdiknas. 2008. Panduan Pengembangan Bahan Ajar. (https:// www. slideshare .net/ mobile/ mmubaraq/ panduanpengembangan -bahan -ajar. Diakses 15 Februari 2016.

Hamalik, O. 2011. Kurikulum dan Pembelajaran. Jakarta: Bumi Aksara.

Khalilullah, M. 2012. Permainan Teka-Teki Silang sebagai Media dalam Pembelajaran Bahasa Arab (Mufradat). Jurnal Pemikiran Islam, (Online), 37 (1). Diakses 5 Desember 2015.

Maret, Ervina. 2009. Pengembangan Perangkat Pembelajaran Kooperatif Tipe Group Investigation Topik Limit Fungsi Aljabar Pada Siswa Kelas XI. Jurnal Pendidikan MIPA, (http://ikippgrimadiun. ac.id/pdf). (Online), 1(2). Diakses 7 Juli 2016.
Resfianti, R. 2015. Pengembangan Lembar Kerja Siswa Berbasis Picture and Picture dalam Pembelajaran Biologi di SMA Negeri 1 Palupuh. Skripsi tidak diterbitkan.

Batusangkar: Program Studi Pendidikan Biologi.

Sudijono, A. 2012. Pengantar Evaluasi Pendidikan. Jakarta: RajaGrafindo Persada.

Trianto. 2010. Model Pembelajaran Terpadu Konsep, Strategi, dan Implementasinya Dalam Kurikulum Tingkat Satuan Pendidikan (KTSP). Jakarta: Bumi Aksara.

Uinsby. 2011. bab\%202 (http:// digilib.uinsby.ac.id/8218/5/bab\% 202.pdf. Diakses 5 Desember 2015 .

Wasgito dan Setiadarma. 2014. Pengembangan Media Permainan Edukatif Teka Teki Silang (TTS) dalam Proses Pembelajaran Siswa Kelas VII SMP Negeri 2 Kalianget. Jurnal Pendidikan Seni Rupa, (http://ejournal.unesa.ac.id), (Online), 2 (3) Diakses 16 Februari 2016.

Widjajanti, E. 2008. Kualitas Lembar Kerja Siswa. (http://staff.uny.ac. idsystem/ files/ pengabdian/ endang widjajanti- lfx- ms- dr/ kualitas-lks.pdf. Diakses 15 Februari 2016. 